\title{
THE GEOCHEMISTRY OF A SUITE OF ECLOGITE XENOLITHS FROM THE RIETFONTEIN KIMBERLITE, SOUTH AFRICA
}

\author{
Clare M. Appleyard ${ }^{1}$, Anton P. le Roex ${ }^{2}$ and Dave R. Bell ${ }^{2}$ \\ ${ }^{1}$ De Beers GeoScience Centre, South Africa ${ }^{2}$ Exploration Geophysics Ltd, Australia
}

\section{INTRODUCTION}

The Rietfontein kimberlite is a barren, off-craton kimberlite pipe. It is located west of the Kaapvaal Craton and is intruded into the Rehoboth subprovince. This Group I kimberlite has been dated at $71.9 \mathrm{Ma}$ (Davis, 1977) and hosts a range of xenocryst lithologies, including peridotite, eclogite and a suite of megacryst minerals. This study focuses on a suite of eclogite xenoliths, which were subject to a detailed petrographical and geochemical study, aimed at their characterisation and comparison to eclogites from oncraton and other off-craton localities. Garnet, clinopyroxene, accessory and secondary minerals were analysed for major element compositions using electron microprobe techniques and garnet and clinopyroxene trace element compositions determined by Laser Ablation Inductively-Coupled-Plasma Mass Spectrometry (LA-ICP-MS) techniques. Oxygen isotopic compositions of five garnet samples were obtained using laser flourination techniques, followed by analysis by gas source mass spectrometry.

\section{PETROGRAPHY}

Three petrographically distinct eclogite groups can be identified viz. bimineralic, opx-bearing and kyanite eclogites. The kyanite eclogites are markedly fresher than the bimineralic and opx-bearing eclogites and contain fewer accessory and secondary minerals. Many of the bimineralic and opx-bearing eclogites are highly altered, with orthopyroxene generally showing more alteration than garnet or clinopyroxene. Triple junctions in many samples indicate good equilibration. Accessory minerals in the eclogites include sulphides, ilmenite and rutile, whereas micas and amphiboles are common secondary minerals. The accessory minerals occur mostly interstitially, whereas the secondary minerals most commonly form alteration rims around the primary minerals. One sample shows an excellent example of garnet exsolution from clinopyroxene (Figure 1).

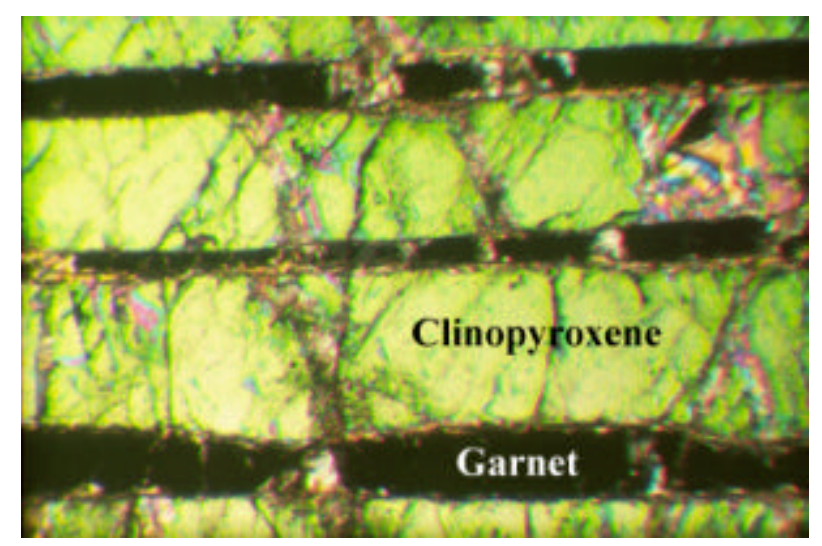

Figure 1: Garnet exsolution lamellae in a large, optically continuous clinopyroxene grain in eclogite sample CMA 1. Lamellae can be up to $0.5 \mathrm{~mm}$ in diameter. Cross-polarised light, $2.5 \mathrm{x}$ magnification, field of view $=3 \mathrm{~mm}$.

Texturally, both Group I and Group II eclogites can be identified (MacGregor \& Carter, 1970), but Group II eclogites dominate the suite. The modal proportions of garnet:clinopyroxene in the samples vary from 70:30 to 30:70, with an average ratio of 49:51, although small sample sizes and large degrees of alteration often made estimates of modal proportions difficult. Kyanite and orthopyroxene both reach a maximum of 20 volume $\%$.

\section{MINERAL CHEMISTRY}

The kyanite eclogites are geochemically distinct from the remaining eclogites with regards to both major and trace element compositions. Garnets from the kyanite eclogites are richer in $\mathrm{Ca}$ (Figure 2) and are Cr-depleted relative to garnets from the bimineralic and opx-bearing eclogites, which tend to be more magnesian. A visual comparison of the end-member components of the Rietfontein eclogitic garnets with garnets from on- and off-craton localities is inconclusive (Figure 2). There is much overlap between the off-craton eclogites, represented by the Cape Province off-craton suite (Robey, 1981) and on-craton eclogites, represented by Roberts Victor eclogites. Clinopyroxenes from the kyanite eclogites are more sodic, with higher $\mathrm{Al}_{2} \mathrm{O}_{3}$ and lower $\mathrm{MgO}$ contents than the bimineralic and opxbearing eclogites. The higher $\mathrm{Na}_{2} \mathrm{O}$ and lower $\mathrm{MgO}$ 


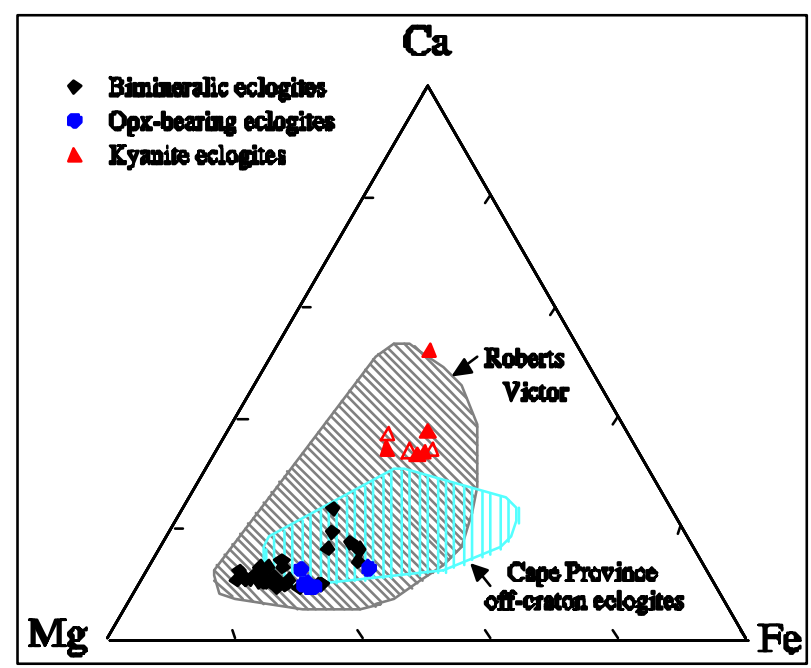

Figure 2: Ca-Mg-Fe ternary diagram for garnets from the Rietfontein eclogites. Data from the off-craton field from Robey (1981); Roberts Victor data from Hatton (1978), MacGregor \& Manton (1986), Ongley et al. (1987), McCandless \& Gurney (1989) and Bell \& Rossman (1992).

contents in clinopyroxenes from the kyanite eclogites result in these eclogites being classified as Group B eclogites (Figure 3), whereas the bimineralic and opxbearing eclogites classify as Group A and Group B eclogites, after the classifications of Taylor \& Neal (1989). Low $\mathrm{Na}_{2} \mathrm{O}_{\mathrm{gt}}$ and $\mathrm{K}_{2} \mathrm{O}_{\mathrm{cpx}}$ concentrations mean that the majority of the Rietfontein eclogites are also Group II eclogites (McCandless \& Gurney, 1989). All primary minerals are homogeneous, indicating compositional equilibrium within the samples.

Garnets from both the bimineralic and opx-bearing eclogites show smoothly varying REE patterns and are relatively depleted in LREE, whereas clinopyroxenes show enrichment in LREE. Garnets and clinopyroxenes from the kyanite eclogites have distinctly different patterns. Garnets exhibit a positive Eu anomaly and clinopyroxenes have an overall convex upwards REE pattern and both are extremely depleted in LREE. Garnets from the kyanite eclogites have Sr, $\mathrm{Sm}$ and $\mathrm{Nd}$ contents greater than the bimineralic and opx-bearing eclogites, whereas clinopyroxenes from the kyanite eclogites have lower REE, Sc and Y abundances than the remaining eclogites. Partitioning of trace elements between clinopyroxene and garnet in the Rietfontein eclogites is shown to be primarily dependent on the $\mathrm{Ca}$ content of garnet, with the more Ca-rich garnets having greatest REE concentrations.

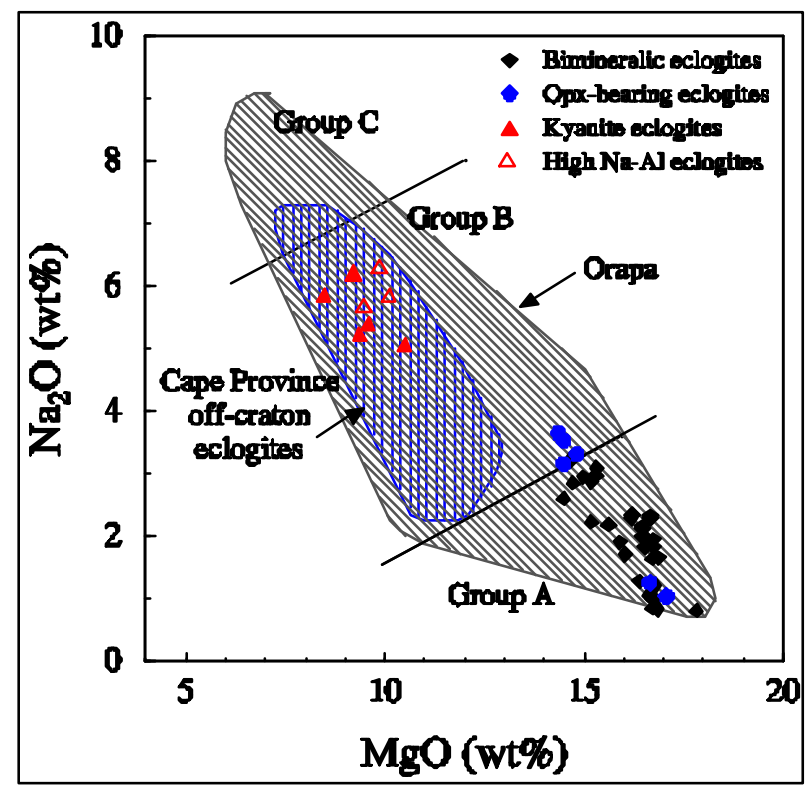

Figure 3: $\mathrm{Na}_{2} \mathrm{O}$ (wt\%) vs $\mathrm{MgO}$ (wt\%) for Rietfontein clinopyroxenes. Orapa data from Shee (1978) and Deines et al. (1991); off-craton data from Robey (1981). Group A, B and $\mathrm{C}$ fields are based on the composition of Bellsbank eclogites, defined by Taylor \& Neal (1989).

\section{WHOLE ROCK CHEMISTRY}

Whole-rock compositions of the eclogites have been reconstructed using equal proportions of garnet and clinopyroxene. In the case of the opx-bearing and kyanite eclogites, the relevant proportions of orthopyroxene and kyanite were also included in the reconstruction. The Rietfontein eclogites are found to be largely basaltic, as is expected of eclogites. The kyanite eclogites are richer in $\mathrm{Na}$ and $\mathrm{Al}$ than the bimineralic and opx-bearing eclogites, which are more magnesian. The kyanite eclogites exhibit compositional similarities to oceanic gabbros and midocean ridge basalts. Most of the Rietfontein eclogites show strong similarities to boninites with regards to their $\mathrm{MgO}, \mathrm{CaO}$ and $\mathrm{Na}_{2} \mathrm{O}$ contents. The kyanite eclogites have distinctly different whole-rock REE patterns when compared to the opx-bearing and kyanite eclogites, with strong LREE depletion and positive $\mathrm{Eu}$ anomalies being exhibited. The bimineralic and opxbearing eclogites exhibit a range of patterns, mostly flat or showing a regular transition from relative LREE enrichment to relative HREE depletion. (Figure 4). 


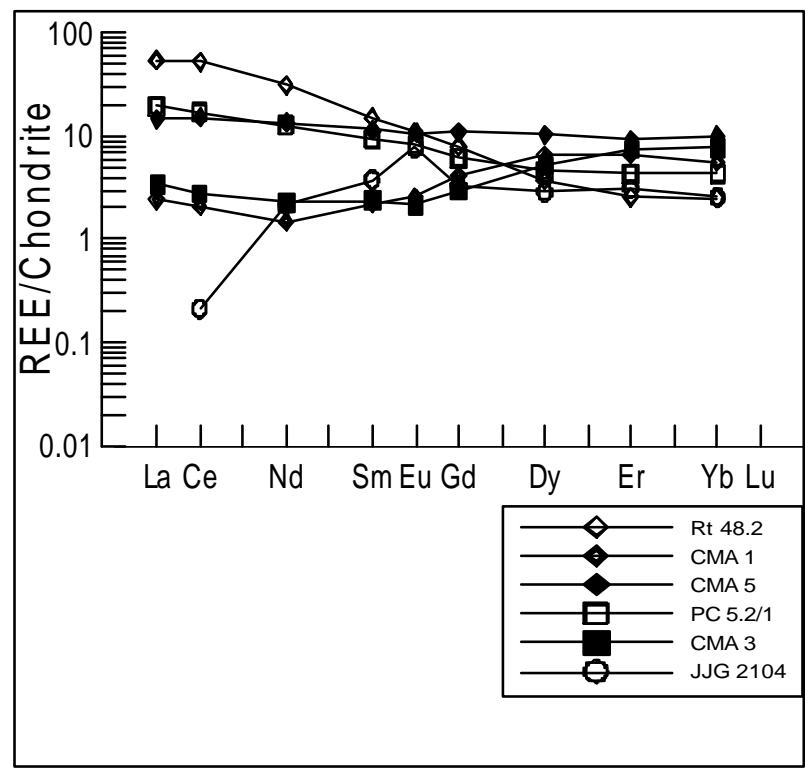

Figure 4 Reconstructed whole-rock REE abundances of selected bimineralic (diamonds), opx-bearing (squares) and kyanite (circles) eclogites. Concentrations are chondrite normalised after Sun \& McDonough (1989).

\section{OXYGEN ISOTOPES}

Oxygen isotope compositions of garnets from five Rietfontein eclogites range from 5.16-6.84\%o. The most Ca-rich sample, a kyanite eclogite, exhibits the highest $\mathrm{d}^{18} \mathrm{O}$ values, whereas the most $\mathrm{Mg}$-rich garnets exhibit the lowest $\mathrm{d}^{18} \mathrm{O}$ values. If one disregards the outlier value of $6.84 \%$, all data for the Rietfontein garnets fall within the "normal" mantle range of 5$6.5 \%$, defined by Deines et al. (1991), as well as the range of $5.5 \pm 0.7 \%$ for ultramafic upper mantle xenoliths (Mattey et al., 1994). The oxygen isotope data thus provides no clear evidence of a crustal precursor.

\section{GEOTHERMOBAROMETRY}

The major element compositions of garnet, clinopyroxene and, in the case of the opx-bearing eclogites, orthopyroxene, were used to calculate equilibration pressures and temperatures of the Rietfontein eclogites. The results indicate derivation from mantle depths, with temperatures of $733-1000^{\circ} \mathrm{C}$ (Krogh, 1988) and pressures of 24-39kb (Brey \& Köhler, 1990) having been estimated. This large range in equilibration pressures and temperatures represents a significant range in mantle stratigraphy and the higher average equilibration temperatures of the kyanite eclogites provide evidence for derivation of these eclogites from greater depths than that of the bimineralic and opx-bearing eclogites. Geotherms constructed from the temperature and pressure estimates of the opx-bearing eclogites yield heat flow approximations of $41-44 \mathrm{~mW} . \mathrm{m}^{-2}$, most similar to geotherms for established on-craton areas.

\section{CONCLUSIONS}

The unambiguous differences in composition and equilibration conditions between the kyanite eclogites and the bimineralic/opx-bearing eclogites indicate that the Rietfontein eclogites represent samples from two distinct eclogite sources situated at depth. A model is proposed whereby all three groups of eclogites originate as unrelated remnants of oceanic crustal material, with one body represented by the kyanite eclogites, the other by the bimineralic and opx-bearing eclogites. Subduction of plagioclase-rich, basaltic oceanic crust to eclogite facies depths would yield eclogites with compositional characteristics similar to those of the Rietfontein kyanite eclogites, viz. positive $\mathrm{Eu}$ anomalies and $\mathrm{Na}-$ and Al-rich whole rock compositions. In contrast, subduction, hydrothermal alteration and metamorphism to eclogite of an oceanic crustal section consisting of basalt, gabbro and boninite is suggested to be the source of the Rietfontein bimineralic and orthopyroxene-bearing eclogites. Underplating of the continental lithosphere by these unrelated eclogite bodies would then allow the Rietfontein kimberlite to separately sample each eclogite body as it ascended towards the surface.

\section{REFERENCES}

Bell, D.R., Rossman, G.R., 1992. The distribution of hydroxyl in garnets from the subcontinental mantle of Southern Africa. Contributions to Mineralogy and Petrology $111,161-178$

Brey, G.P., Köhler, T., 1990. Geothermobarometry in Fourphase lherzolites II. New thermobarometers and practical assessment of existing thermobarometers. Journal of Petrology 31, 1353-1378.

Davis, G.L., 1977. The ages and uranium contents of zircons from kimberlites and associated rocks. Carnegie Institute of Washington Yearbook 76, 631-635.

Deines, P., Harris, J.W., Robinson, D.R., Gurney, J.J., Shee, S.R., 1991. Carbon and oxygen isotope variations in 
diamond and graphite eclogites from Orapa, Botswana and the nitrogen content of their diamonds. Geochmica et Cosmochimica Acta 55, 515-524.

Hatton, C.J., 1978. The geochemistry and origin of xenoliths from the Roberts Victor Mine. Ph.D. Thesis, University of Cape Town, Cape Town, South Africa.

Krogh, E.J., 1988. The garnet-clinopyroxene $\mathrm{Fe}-\mathrm{Mg}$ thermometer - a reinterpretation of existing experimental data. Contributions to Mineralogy and Petrology 99, 44-48.

MacGregor, I.D., Carter, J.L., 1970. The chemistry of clinopyroxenes and garnets of eclogite and peridotite xenoliths from the Roberts Victor Mine, South Africa. Phys. Earth Planet. Interiors 3, 391-397.

MacGregor, I.D., Manton, W.I., 1986. Roberts Victor eclogites: ancient oceanic crust. Journal of Geophysical Research 91, 14063-14079.

Mattey, D., Lowry, D., MacPherson, C., 1994. Oxygen isotope composition of mantle peridotite. Earth and Planetary Science Letters 128, 231-241.

McCandless, T.E., Gurney, J.J., 1989. Sodium in garnet and potassium in clinopyroxene: criteria for classifying mantle eclogites. In Ross, J. (Ed), Kimberlites and related rocks Vol 2 Their mantle/crust setting, diamonds and diamond exploration. Blackwell, Carlton, pp. 827-832.

Ongley, J.S., Basu, A.R., Kyser, T.K., 1987. Oxygen isotopes in coexisting garnets, clinopyroxenes and phlogopites of Roberts Victor eclogites: implications for petrogenesis and mantle metasomatism. Earth and Planetrary Science Letters 83, 80-84.

Robey, J.v.A., 1981. Kimberlites of the Central Cape Province, R.S.A. Ph.D. Thesis, University of Cape Town, Cape Town, South Africa.

Shee, S.R., 1978. The mineral chemistry of xenoliths from the Orapa kimberlite pipe, Botswana. Ph.D. Thesis, University of Cape Town, Cape Town, South Africa.

Sun, S-s., McDonough, W.F., 1989. Chemical and isotope systematics of oceanic basalts: implications for mantle composition and processes. In Saunders, A.D.N., Norry, M.J. (Eds), Magmatism in the ocean basins, Geological Society Special Publication 42, pp. 313345.

Taylor, L.A., Neal, C.R., 1989. Eclogites with oceanic crustal and mantle signatures from the Bellsbank kimberlite, South Africa Part 1: mineralogy, petrography and whole-rock chemistry. Journal of Geology 97, 551567.

Contact: CM Appleyard, PO Box 82232, Southdale, 2135 ,

South Africa, E-mail: clare.appleyard@ debeersgroup.com 